\title{
A Research on Friction Stir Welding using M42 Tool on Aisi 1018 Steel Plates
}

\author{
Vinayagamoorthi M A, Prince M, Mohan Kumar R S
}

\begin{abstract}
Friction Stir Welding was mainly suitable for aluminum alloys due to low softening temperatures. It is challenging to join the high melting temperature metals due to the lack of tool materials. The main focus of this work is to study the feasibility of joining the similar or dissimilar ferrous material. The molybdenum based high speed steel acts a rotating non consumable tool to weld the two ferrous plates. The friction stir welding was achieved using vertical milling machine. Welding samples were examined by destructive and nondestructive test. The welds were produced by $3 \mathrm{~mm}$ plate over a range of spindle speed from 500 to $1000 \mathrm{rpm}$. The results of FSW, stir zone of hardness varies from 139 to $145 \mathrm{HV}$ executed on AISI 1018 plate steel.
\end{abstract}

Keywords- Vertical Milling machine, Friction Stir Welding(FSW), Molybdenum High speed steel Tool (M42).

\section{INTRODUCTION}

Friction stir welding (FSW) is a solid state joining process developed by The Welding Institue.It is a process that uses a non-consumable rotating tool to joining the metals. In this a non-consumable tool consists of shank, shoulder and pin. The tool material is always tougher than the work material. During rotation tool was plunged into the weld line of the work material and consequently travel along the weld line.

Heat is generated due to the rotation of tool shoulder bottom face against the work material and it is soft and deform plastically. The pin of the tool stirs the work material and generates heat by friction during this process material being welded. Tool shoulder controls and supports the flow of material and formation.

Various tool classes have been used to perform FSW and processing. The most commonly used tool steel is H13 which is used to weld most aluminium alloys, magnesium, lead, and other low-softening temperature materials. Cobaltand nickel-base super alloys have been used as materials for FSW tools in high-strength aluminium, copper, and thin steels. Refractory metals are promising FSW tool materials for high-softening-temperature alloys because of their very high hot strength. Super abrasives are ceramic materials that have been processed in high temperature, ultra-highpressure presses. The most widely known super abrasive is synthetic diamond. It is used for FSW tools in the form of a sintered compact called polycrystalline diamond (PCD).

Revised Manuscript Received on September 14, 2019.

Vinayagamoorthi M A, Asst. Professor, Dept. of Mechanical Engineering, Kumaraguru College of Technology, Coimbatore, Tamilnadu, India.(Email: vinayagamoorthi.ma.mec@kct.ac.in)

Prince M, Professor, Dept. of Mechanical Engineering, Sri Krishna College Technology, Coimbatore, Tamilnadu, India.(Email: drprince1977@gmail.com)

Mohan Kumar R S, Asst. Professor, Dept. of Mechanical Engineering, Kumaraguru College of Technology, Coimbatore, Tamilnadu, India.(Email: mohankumar.rs.mec@kct.ac.in)
Friction stir welding process involves in movement of material and deformation due to parameters of welding such as speed, feed and plunge depth. Tool shape, size and material are significant factors in the flow of material and temperature distribution.

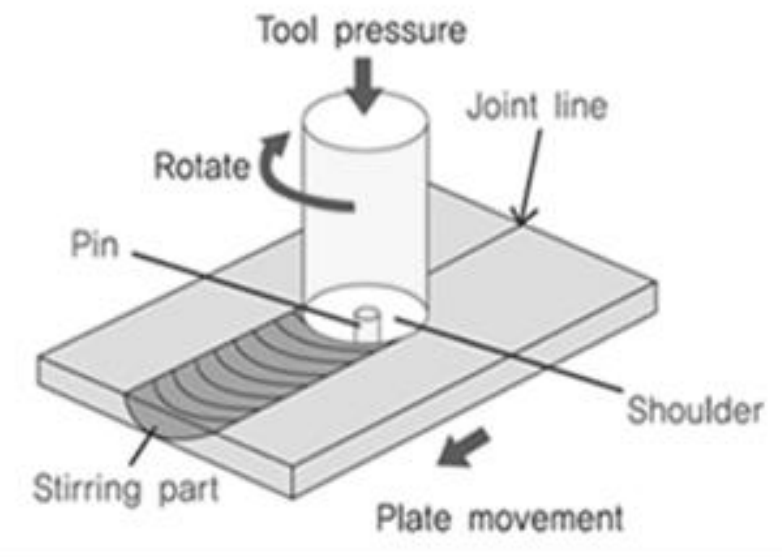

Fig.1 Friction stir welding process

\section{TOOL MATERIAL SELECTION}

Friction stir welding tool consist of a shank, shoulder and a pin. The shoulder is larger in diameter than the probe and rides along the joint at or near the surface of the work piece. Material properties based on mechanical such as strength, fracture and hardness, thermal properties such as conductivity and expansion affect the quality of weld and efficiency. Increase in tool rotational speed for friction stir welding of mild steel, therefore work material temperature increases [1]. Hence enhances the tool durability. It is also observed that tool materials with high strength and hardening to withstand high melting temperature is highly required to improve the quality of weld [2].

To improve the mechanical properties of high temperature and high strength alloy work materials, tool design is a significant factor in friction stir welding [3]. Material selection and geometry of FSW tool are also considered as key aspects to enhance the tool life and to achieve the defect free weld [4]. The effect of both plunge depth and fused area is to be considered in FSW inorder to evaluate the joint strength and fatigue strength [5].

\section{MOLYBDENUM BASED HIGH-SPEED STEELS}

The principal alloying elements are molybdenum, chromium, vanadium, tungsten, cobalt, and carbon. In type $\mathrm{M}$ tool steels have larger toughness than group $\mathrm{T}$ type tool steels. These type of tools have high resistance to softening at elevated temperatures.

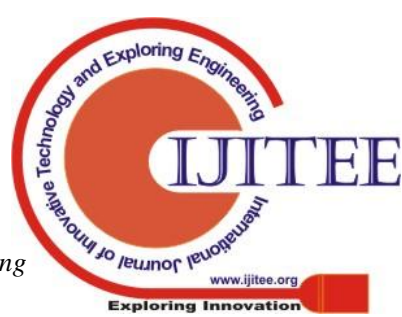


The M42 tool are tougher than the Tungsten type tool steels. Also hardness and wear resistance are higher for molybdenum based HSS compare to tungsten based HSS. And also lower cost compared to tungsten and Polycrystalline cubic boron nitride (PCBN) tools. From various molybdenum based HSS grades we have to select suitable grade satisfying required tool characteristics. we have to understand that M42 has higher hardness, resistance to softening highest, resistance to wear also high. So M42 is chosen as tool material.

\section{TOOL DESIGN}

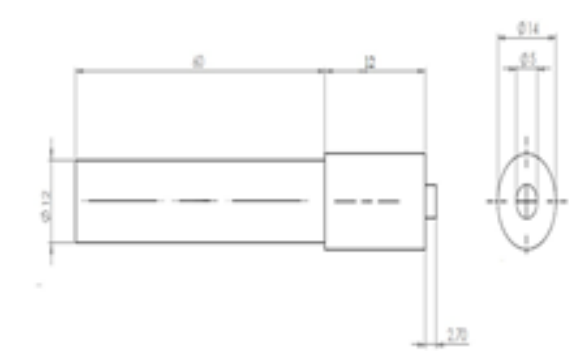

Fig.2 FSW Tool

Shoulder diameter (Ds),

Ds $=2.2 \times$ Work piece thickness +7.3

$=2.2 \times 3+7.3$

Ds $=13.9 \mathrm{~mm}$

Probe diameter $(\mathrm{Dp})$,

$\mathrm{Dp}=0.8 \times$ Work piece thickness +2.2

$=0.8 \times 3+2.2$

$\mathrm{Dp}=5 \mathrm{~mm}$

Pin length (Lp),

$\mathrm{Lp}=$ Work piece thickness -0.3

$\mathrm{Lp}=3-0.3=2.7 \mathrm{~mm}$

Shoulder length (Ls),

Ls $=$

$\mathrm{Ls}=4.2 \times 2.7=11.34=12 \mathrm{~mm}$

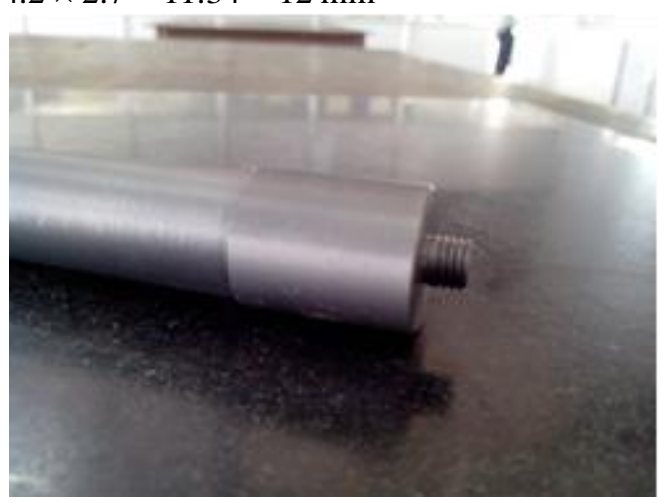

Fig.3 FSW Tool after Machining

From hardness test of tool material, the test result of hardness is $30 \mathrm{HRC}$, the hardness of tool material is low compared to work material. So it needs hardening process. After hardening HRC Achieved is in between 60 and 62 .
Table I. Hardening Process Details

\begin{tabular}{|l|c|c|}
\hline \multicolumn{1}{|c|}{ Operation } & $\begin{array}{c}\text { Temperatur } \\
\text { e }\end{array}$ & Time \\
\hline $\begin{array}{l}\text { 1 Pre Heat } \\
\text { Temperature }\end{array}$ & $650^{\circ} \mathrm{C}$ & 90 minutes \\
\hline $\begin{array}{l}\text { 2 Pre Heat } \\
\text { Temperature }\end{array}$ & $825^{\circ} \mathrm{C}$ & 45 minutes \\
\hline $\begin{array}{l}\text { 3 Pre Heat } \\
\text { Temperature }\end{array}$ & $1075^{\circ} \mathrm{C}$ & 30 minutes \\
\hline $\begin{array}{l}\text { Austenizing } \\
\text { Temperature }\end{array}$ & $1180^{\circ} \mathrm{C}$ & 15 minutes \\
\hline 1 Tempering & $540^{\circ} \mathrm{C}$ & 120 minutes \\
\hline subzero & $-70^{\circ} \mathrm{C}$ & 240 minutes \\
\hline 2 Tempering & $560^{\circ} \mathrm{C}$ & 120 minutes \\
\hline 3 Tempering & $570^{\circ} \mathrm{C}$ & 120 minutes \\
\hline
\end{tabular}

\section{WORK MATERIAL}

The AISI 1018 work material is involved in this experimental work to study the feasibility of friction stir welding by using M42 tool. It has good weld ability in all conventional welding processes. It has a relatively low tensile strength and easy to form.

Table II. Chemical composition - AISI 1018

\begin{tabular}{|c|c|c|c|c|}
\hline $\mathbf{C}$ & $\mathbf{P}$ & $\mathbf{M n}$ & $\mathbf{S}$ & $\mathbf{F e}$ \\
\hline 0.14 & 0.040 & 0.70 & 0.05 & 98 \\
\hline
\end{tabular}

A chemical composition of mild steel AISI 1018 shown in table II and used as a work material for this experimental study in FSW welding. The dimension is taken as $100 \mathrm{~mm}$ length, $50 \mathrm{~mm}$ breadth and $3 \mathrm{~mm}$ thickness.

Table III. Properties of AISI 1018 mild steel

\begin{tabular}{|l|l|}
\hline \multicolumn{1}{|c|}{ Properties } & \multicolumn{1}{c|}{ Values } \\
\hline Density & $7.87 \mathrm{~g} / \mathrm{cc}$ \\
\hline Tensile strength, YS & $370 \mathrm{MPa}$ \\
\hline Tensile strength, UTS & $440 \mathrm{MPa}$ \\
\hline Poisson's ratio & 0.290 \\
\hline Reduction of area & $40 \%$ \\
\hline Hardness & Brinell 126 \\
\hline Modulus of Elasticity & $205 \mathrm{GPa}$ \\
\hline Bulk modulus & $140 \mathrm{GPa}$ \\
\hline
\end{tabular}

\section{EXPERIMENTAL WORK}

Milling machine with Digital Read Out (DRO) is used for FSW process and to find the operating parameters. Normally, FSW machine is used for welding the low melting temperature alloys but its operating cost very high. 


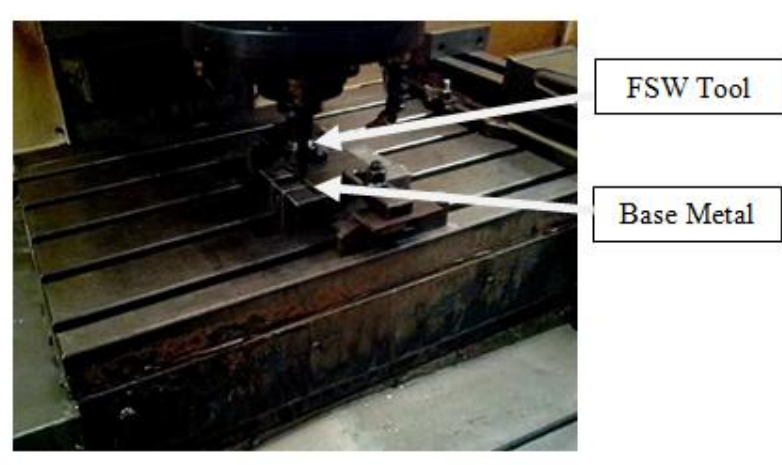

Fig.4 Experimental setup on Milling machine with Digital Read Out

The proper heat production occurs at $500 \mathrm{rpm}$ so it chosen as lower limit. High speed input may cause tool failure so maximum speed for proper welding is taken as 1000 rpm.DRO milling machine is manually controlled so feed selected according to workers convenience. The maximum feed rate is chosen as $60 \mathrm{~mm} / \mathrm{min}$ and minimum feed rate is $30 \mathrm{~mm} / \mathrm{min}$. Parameter selection is important characteristic in a experimental work. Proper selection of parameters will extend the life of tools and it also produce good weld.

After selecting the welding parameter the work material has been clamped in the position of butt joint configuration. The welding were performed in vertical milling machine and the non consumable rotating tool was made of molybdenum based M42 HSS.During welding $3 \mathrm{~mm}$ thick plates of AISI 1018 steel with the clockwise direction of tool.A $14 \mathrm{~mm}$ diameter of shoulder and length of the pin was $2.7 \mathrm{~mm}$, which is less than work material thickness.welding performed at feed rate ranging from 30 to $60 \mathrm{~mm} / \mathrm{min}$, and the tool rotated at 400 to 800 revolutions per minute.Three samples were prepared by VMC machine.

Table IV. Welding Parameters

\begin{tabular}{|c|c|c|c|c|}
\hline \multirow{2}{*}{$\begin{array}{l}\text { S. } \\
\text { No. }\end{array}$} & \multicolumn{4}{|c|}{ Operating parameters } \\
\cline { 2 - 5 } & Particulars & $\begin{array}{c}\text { Sample } \\
\mathbf{1}\end{array}$ & $\begin{array}{c}\text { Sample } \\
\mathbf{2}\end{array}$ & $\begin{array}{c}\text { Sample } \\
\mathbf{3}\end{array}$ \\
\hline 1 & $\begin{array}{c}\text { Spindle } \\
\text { speed (rpm) }\end{array}$ & 1000 & 750 & 500 \\
\hline 2 & $\begin{array}{c}\text { Feed rate } \\
(\mathrm{mm} / \mathrm{min})\end{array}$ & 60 & 45 & 30 \\
\hline
\end{tabular}

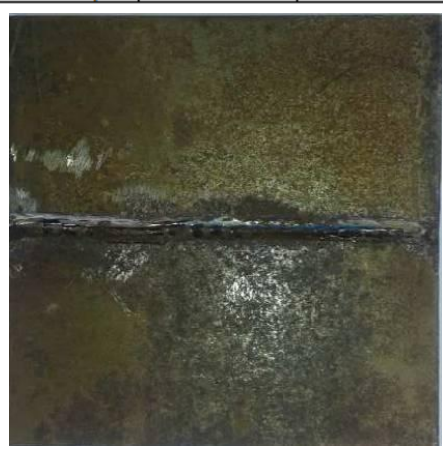

Fig.5 FSW sample

\section{RESULTS AND DISCUSSION}

The base material exhibited a microstructure of fine and smaller grains of pearlite.The weld region shows various microstructurally distinct formations made in the weld
centerline.Flow plath and lines are indications of deformation.

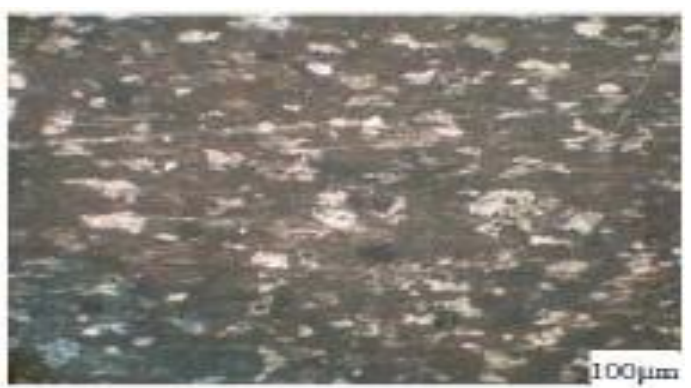

Fig.6 Optical micrograph of base metal

HAZ experiences only thermal cycles.some part of the this zone is unaffected base metal region.The transient formation is, critical close to the centerline of weld.At a certain distance from the weld, depending on the maximum temperature and effect of the transient will be considerably small.As for the nugget, the processes that occur in the heat affected zone will depend on the alloy being considered.

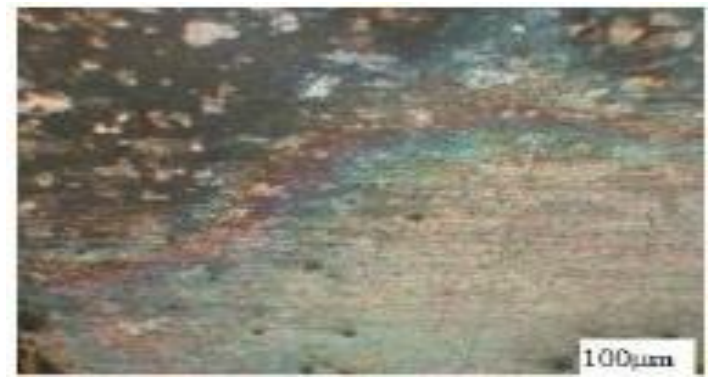

Fig.7 Optical micrograph of HAZ

In the stir zone microstructural evolution is difficult to interpret as that in the HAZ. While the HAZ and stir zone experiences thermal cycle and mechanical cycles respectively.Hence, effects of the both thermal and mechanical cycle must be considered. In the stir zone shows the structures from ferrite to fine pearlite.Stir zone and therm mechanically affected zone experience both temperature and deformation. It concludes the very fine grain size that results from the large strains and high strain rates practiced with the material in direct contact with the shoulder.

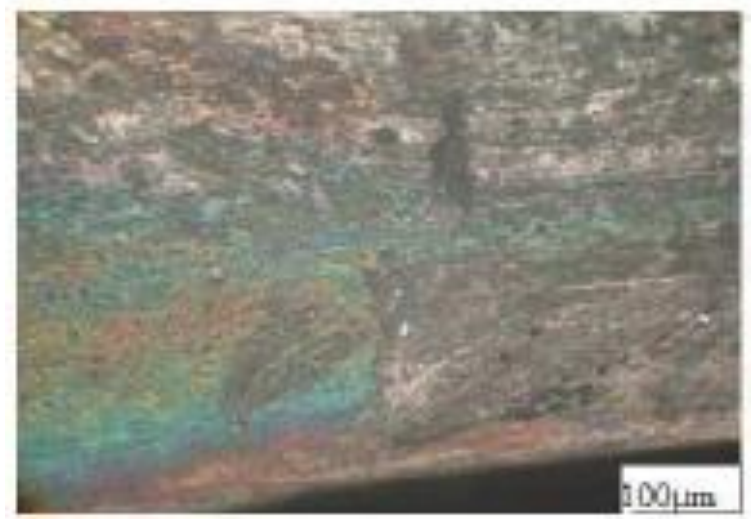

Fig.8 Optical micrograph of stir zone

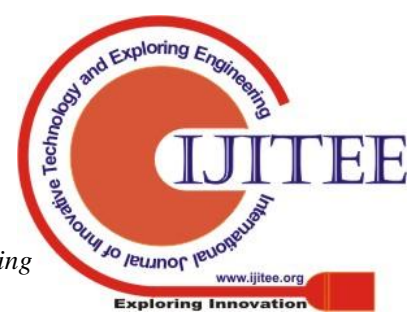


Tensile strength reflects the behaviour of a material under various loads other than uniaxial tension. The tensile strength is observed in terms of stress to cause significant plastic deformation.These strength are used in engineering design to avoid fracture and caution in it. And also attention of ductility and relevant mechanical properties. During testing elastic properties must be measured these properties, and using ultrasonic techniques to get accurate measurements.

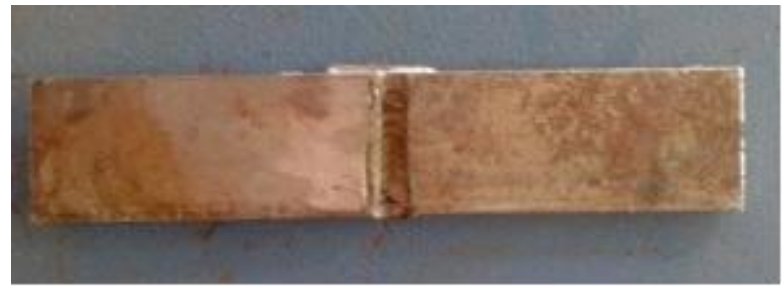

Fig.9 Tensile specimen before fracture

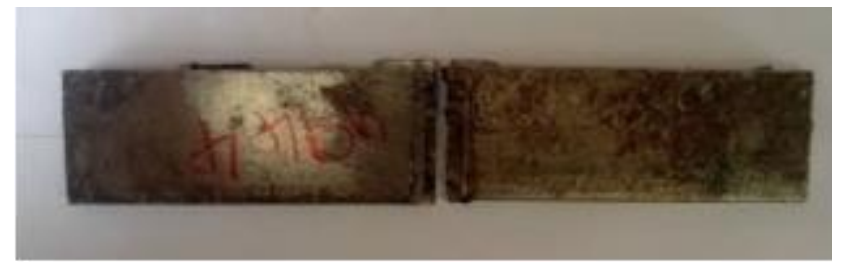

Fig.10 Tensile specimen after fracture.

According to tensile test it understood that the weld can withstand 185Mpa to $221 \mathrm{Mpa}$.

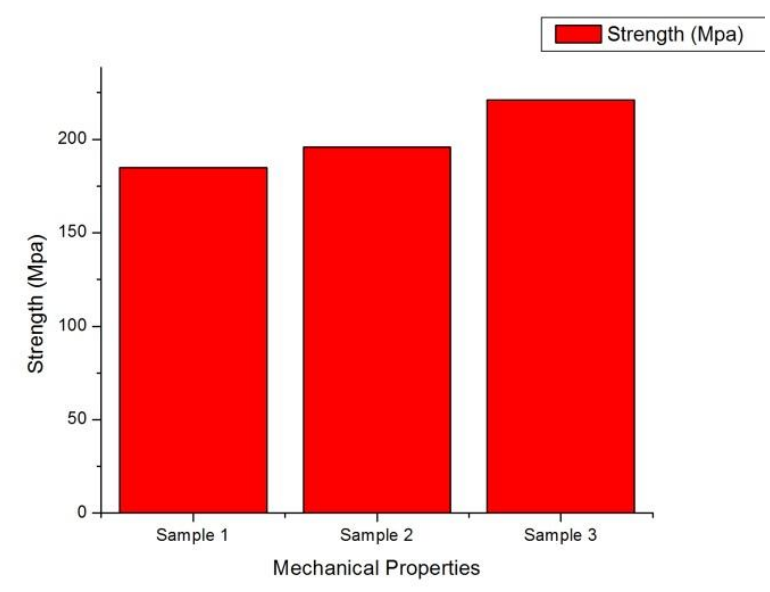

Fig.11 Tensile Strength of samples with various parameters

\section{Macro Hardness}

Rockwell hardness test is used for the measuring hardness of materials with recommended load for certain seconds.And it is based on the total increase in depth of impression.

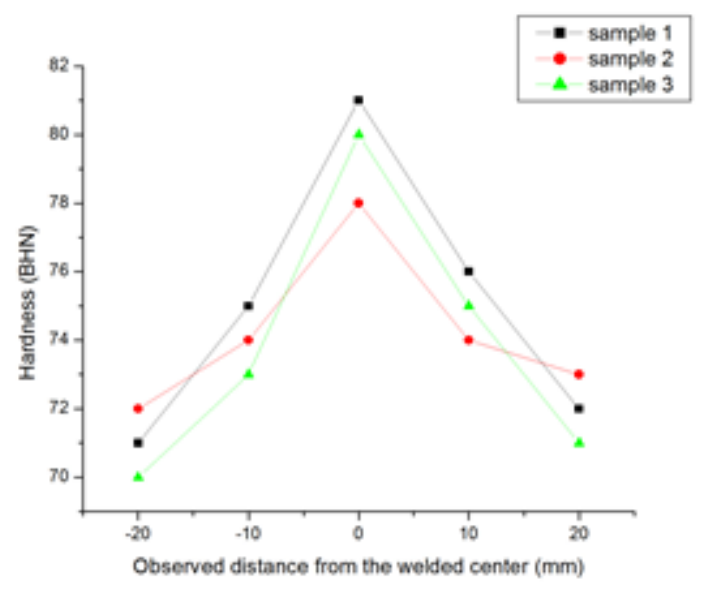

Fig.12 Hardness of Work Material

The hardness of work material increased from $71 \mathrm{HRB}$ to $81 \mathrm{HRB}$, so resistance to plastic deformation increased by Friction stir welding.

\section{Micro Hardness}

Vickers Hardness test is used for measuring the hardness of a welded samples. The hardness point located from weld line on both sides of advancing side and retreating side.

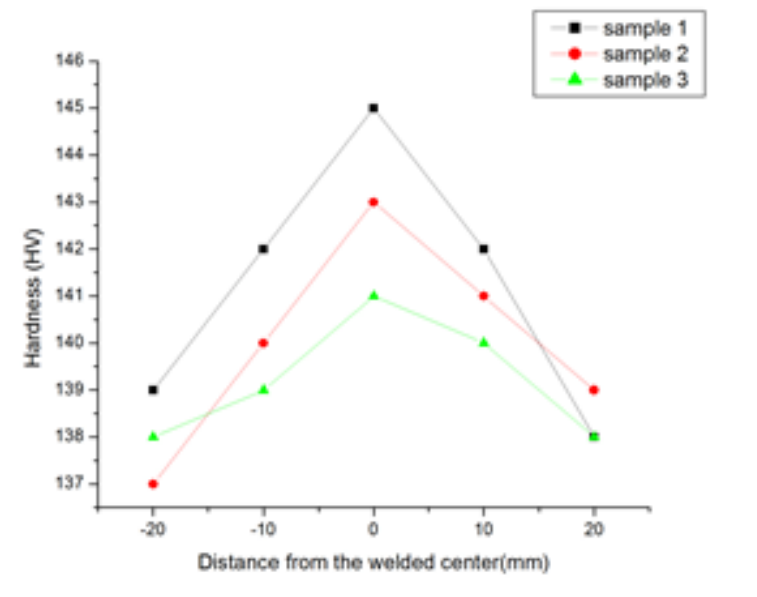

Fig.13 Hardness of Welded region

The welding process is performed on two similar materials of AISI 1018 steel with butt joint configuration. When the observed hardness values in nugget zone are greater than the base material hardness, which is varies from 139 to $145 \mathrm{HV}$.The increasing of hardness is due to the formation of ferrite with fine equiaxed grains.

\section{CONCLUSION}

Defect-free friction stir welds can be produced in $3 \mathrm{~mm}$ plate by using vertical milling machine with M42 tool ranges of spindle speed from 500 to $1000 \mathrm{rpm}$. The cost efficient tool for FSW process is obtained.Tensile strength of the weld is moderately improved due to effective material coaselence with increasing speed during the process.And also tensile strength of welded joints were found to be 
decreased compared to base metal due to the formation of tool debris. Hardness of friction stir welded joints improved compared with the base metal. This is reason of fine structure of ferrite and pearlite in the weld zone.Results indicates the feasibility of welding mild steel with significant improved hardness and moderate improvement in tensile strength.

\section{REFERENCES}

1. A. De1, H. K. D. H. Bhadeshia- Friction Stir Welding of Mild Steel - Tool Durability and Steel MicrostructureMaterials science and technology 30 (2014).

2. Akos Meilinger, ImreTorokUniversity of Miskolc, Department of Mechanical Technology - the importance of friction stir welding tool Production Processes andSystems, vol. 6. (2013).

3. Y. N. Zhang, X. Cao, S. Larose and P. Wanjara - Review of tools for friction stir welding and processing. Canadian Metallurgical Quarterly 2012 Vol 51.

4. R. Rai, A. De, H. K. D. H. Bhadeshia and T. DebRoyReview on friction stir welding tools .Science and Technology of Welding and Joining 2011 Vol 16.

5. Md Shamsujjoha, Sharat K. Jasthi1, Michael Wesf and Christian Widener,Microstructure and Mechanical Properties of FSW Lap Joint between Pure Copper and 1018 Mild Steel Using Refractory Metal Pin Tools, The Minerals, Metals \& Materials Society, Friction Stir Welding and Proceesing VII,2013. 